\title{
Apocalypse Now? Body, Soul and Judgment in the Christianisation of the Anglo-Saxons
}

Apocalyptic was not, as is sometimes asserted, a good starting point for those engaged in the conversion of England to Christianity in the period around $600 \mathrm{CE}$ : this chapter argues that it took about two hundred years for issues such as Christian apocalyptic and the Last Judgment to be properly foregrounded. Before this could be achieved, the Anglo-Saxon Church had to overcome the gulf between Christianity and indigenous Anglo-Saxon religions whose primary focus was on positive outcomes survival, health, prosperity - in this life. Burial of converts with grave goods, which might even initially include Christian objects understood as "other-world passports", reflect the persistence for nearly a century, of belief in funerary ritual as a rite of transition to a relatively undifferentiated afterlife. The chapter discusses the adjustments and accommodations by which the Church attempted to make its teaching comprehensible, particularly in the articulation of its doctrine on the nature of the soul and the development of its thinking about the Christian interim afterlife. It shows that the idea of Judgment was not particularly compatible with elite expectations; and also that problems were created by disagreements within the Church over whether there was a place in the Christian afterlife for the souls of unbaptised ancestors. Finally, it discusses the way in which the promotion of the Christian concept of linear (as opposed to cyclical) time and Anno Domini dating marked significant steps in the Church's progress towards more explicit presentation of the Last Judgment and Christian apocalyptic.

Writing to the Anglo-Saxon ruler Æthelbehrt of Kent in 601 at the point of his conversion to Christianity, Pope Gregory I summoned up apocalyptic images of the end of the world:

[...] we would wish your Majesty to know that the end of the world is at hand, as we learn from the words of Almighty God in the Holy Scripture; and the kingdom of the saints which knows no end is near. As the end of the world approaches, many things happen which have never happened before; these are changes in the sky and terrors from the heavens, unseasonable tempests, war, famine, pestilence and earthquakes in divers places. Not all these things will come about in our days, but they will all follow after our days. So if you see any of these things happening in your land, do not be troubled in mind; for these signs of the end of the world are sent in advance to make us heedful about our souls, watching for the hour of death, so that when the Judge comes, we may, through our good works be found prepared. ${ }^{1}$

\footnotetext{
1 Gregory the Great, Registrum Epistularum, 11.37, ed. Norberg, 929-932. Bede, Historia ecclesiastica 1.32; Bede's Ecclesiastical History, ed. and trans. Colgrave and Mynors, 112-115.

2 Open Access. (c) 2020 Marilyn Dunn, published by De Gruyter. (ङ) BY-NC-ND This work is licensed under the Creative Commons Attribution-NonCommercial-NoDerivatives 4.0 License.

https://doi.org/10.1515/9783110597745-023
} 
There have been recent suggestions that apocalypticism, a "key element" of Gregory's theological perspective, would prove instructive for Æthelberht and even that, through this letter, Gregory was attempting to teach him "to use the apocalyptic to his advantage in urging others to conversion". ${ }^{2}$ In reality, Gregory had very limited experience of dealing with pagans and we might legitimately wonder about the effectiveness of raising these matters. Æthelberht had received the mission sent out by Gregory in 597, but the letter Gregory sent to the king's Christian Frankish wife at the same time makes it plain that she had taken no steps to school her husband in the Christian faith either then or at any previous point in their marriage. ${ }^{3}$ In 601 , Æthelberht was a very new Christian indeed and it is far from clear that he would have been able to comprehend all the elements of Christian apocalyptic which Gregory confidently lays before him. We can assume that the king would have known "changes in the sky and terrors from the heavens" (inmutationes aeris, terroresque de caelo), tempests, war, possibly famine and almost certainly pestilence (though earthquakes were probably outside his experience). We can also assume that he is likely to have been familiar with predictions and inferences from such "signs". But the essential matters of Christian apocalyptic - judgment and the judge, souls, the approaching end of the present world and Christian eternity - were quite another matter. All are highly specific to the Christian religion and would require clarification to a person whose views about this life and the afterlife were very different from those taught by Christianity. Far from aiding conversion, Christian apocalyptic would reveal profound differences between Christian doctrine and the religions of the pagan Anglo-Saxons; and over the first two centuries of Christianisation, the early Anglo-Saxon Church would find itself faced with the necessity of making many adjustments and accommodations to bridge the gulf between them. ${ }^{4}$

In teaching Christian apocalyptic and afterlife concepts to the Anglo-Saxons, the Church faced a huge initial disadvantage: it was dealing with people whose religion was world-accepting rather than world-rejecting and focused primarily on this life rather than any life to come. Evidence of sacred springs, groves, altars and animal sacrifices indicates that Anglo-Saxon religions were of the type concerned above all with this world rather than the next; its rituals focused on achieving positive outcomes like health, victory and prosperity. ${ }^{5}$ Studies of conversion to Christianity in modern societies where indigenous religions focus primarily on well-being during life do not suggest that the Christian view of the afterlife has been an important

2 George Demacopoulos, "Gregory the Great and the Pagan Shrines of Kent;" Palmer, The Apocalypse in the Early Middle Ages, 66.

3 Dunn, The Christianization of the Anglo-Saxons, 54-56.

4 For the basic approach of this paper, which makes use of insights provided by the cognitive science of religion, see Dunn, The Christianization of the Anglo-Saxons, 1-6; Dunn, Belief and Religion in Barbarian Europe, 3-8; Whitehouse and Martin, eds., Theorizing Religions Past; Barrett, Why Would Anyone Believe in God?; Boyer, Religion Explained.

5 Wilson, Anglo-Saxon Paganism, 5-66; Dunn, The Christianization of the Anglo-Saxons, 56-83. 
factor in persuading people to convert. On the contrary, Christianity succeeds in such circumstances by focusing strongly on the present life. ${ }^{6}$ The Ecclesiastical History's one and only account of the mass conversion of an Anglo-Saxon people that was neither led nor enforced by a ruler is that of the conversion of the South Saxons in the 680s by Bishop Wilfrid of Northumbria. Arriving in the area after it had been suffering from drought for three years, he taught this people to catch fish, thus putting an end to a major famine. (The drought miraculously ends when the grateful South Saxons are baptised). ${ }^{7}$ The same point is made by Wifrid's hagiographer, Eddius: he fails to mention the fishing miracle in relation to Sussex, but tells a similar tale of another mass conversion, this time of continental paganism in Frisia. ${ }^{8}$ Both Bede and Eddius make it quite clear that in the cases they describe, preaching and teaching alone had proved ineffective. ${ }^{9}$ Whether entirely fictional or partly accurate, both narratives underline the world-accepting nature of Anglo-Saxon religion and the fact that the most effective way to secure conversion to Christianity was to associate the new religion with survival, health and prosperity. Apocalyptic was not a good point from which to start.

In a famous passage of his Ecclesiastical History, Bede claims to give an account of events of just over a century earlier when King Eadwine of Northumbria consulted his thegns about the desirability of becoming Christian. One thegn advises that:

This is how the present life of man on earth [...] appears to me in comparison to that time which is unknown to us (quod nobis incertum est temporis). You are sitting feasting with your ealdormen and thegns in winter time; the fire is burning on the hearth in the middle of the hall and all inside is warm, while outside the wintry storms of rain and snow are raging and a sparrow flies swiftly through the hall. It enters in at one door and quickly flies out through the other. For the few moments that it is inside, the storm and wintry tempest cannot touch it, but after the briefest moment of calm, it flits from your sight, out of the wintry storm and into it again. So this life of man appears but for a moment; what follows or indeed what went before, we know not at all (quid autem sequatur, quidue praecesserit, prorsus ignoramus). ${ }^{10}$

The passage conveys the Anglo-Saxon view that present life is clearly the most desirable state of existence, in the same way that feasting in the king's hall represented the high point of pleasure and reward in the existence of the Anglo-Saxon warrior. ${ }^{11}$ It also reveals the extent of the gulf between Christian and pagan understandings of life after death: Bede concludes the episode by making the thegn go on to advocate conversion - if, that is, the new doctrine offered "something more cer-

\footnotetext{
6 Gifford, "African Christianity and the Eclipse of the Afterlife."

7 Bede, Historia ecclesiastica, 4.13, ed. and trans. Colgrave and Mynors, 372-375.

8 Eddius Stephanus, Vita Wilfridi, 26, ed. and trans. Colgrave, 52-53.

9 Eddius Stephanus, Vita Wilfridi, 26, ed. and trans. Colgrave, 52-53.

10 Bede, Historia ecclesiastica, 2.13, ed. and trans. Colgrave and Mynors, 182-185.

11 Shippey, Beowulf, 23: "The hall equals happiness equals light."
} 
tain" (certius aliquid) about the unknown. ${ }^{12}$ It was easy for the Christian monk to imply that the Anglo-Saxon conception of the afterlife was as uncertain as the thegn's metaphor of the dark, stormy and wintry exterior world is intended to suggest. Religions focused on the here-and-now often characterise the otherworld or spirit-land as a fainter and/or less pleasant or somehow distorted version of existence - even if it is also the place where the spirits of ancestors live. ${ }^{13}$ We have extensive evidence from virtually all areas of Anglo-Saxon England of the customs of burial with grave goods; cremation, generally practised up to the early years of the seventh century; ${ }^{14}$ exposure or reduction of the body and secondary burial; and the dismemberment or partial dismemberment of bodies post-mortem. ${ }^{15}$ These reflect funerary rituals of the type classified by the work of Robert Hertz and Arnold van Gennep in the early twentieth century as rites of transition, designed to conduct the spirit safely into the other world. ${ }^{16}$ Their performance indicates a belief that the soul did not separate immediately from the body on death, but lingered in the vicinity of the living, requiring appropriate rites to transport it to the spirit-land or land of the ancestor. In such belief-systems, there is not necessarily a strong concept of postmortem judgment as in Christianity: the afterlife can be relatively undifferentiated. The punishment of those deemed to have put themselves beyond the social pale in some way may consist in denial of appropriate rites of transition into the ancestral world. However, the absence of correct or complete funerary ritual may also allow the spirit to re-enter the body as a malevolent revenant. ${ }^{17}$

While Pope Gregory had been keen to foreground the Last Judgment in his letter to Æthelberht, the evidence suggests that the Church in England was not in a position to follow his example for some time. Instead, it found itself working with peoples who understood funerary ritual as a rite of transition into an otherworld rather than an afterlife in the Christian sense; and with ruling elites who viewed acceptance or rejection of Christianity within traditional parameters in which adoption of cults of individual deities had formed part of strategies for their own personal advancement. ${ }^{18}$ Thus we find baptismal spoons placed near the head of the person interred in the extraordinarily lavish rite-of-transition Sutton Hoo Mound 1 ship burial; and gold foil crosses placed on the face of the occupant of another magnifi-

12 Bede, Historia ecclesiastica, 2.13, ed. and trans. Colgrave and Mynors, 184-185.

13 Dunn, The Christianization of the Anglo-Saxons, 8-9. For an otherworld as mirror-image of a secular empire see in this volume Frederick Chen, "The Evolution of the Buddhist Other-World Empire in Early Medieval China."

14 See Hines and Bayliss, eds., Anglo-Saxon Graves and Grave-Goods of the 6th and 7th Centuries $A D$, 552, note 7, for later cremation burials at Southampton and Pagham.

15 Dunn, The Christianization of the Anglo-Saxons, 85-100.

16 Hertz, "A Contribution to the Study of the Collective Representation of Death;" Gennep, Rites of Passage, 146-165; Metcalf and Huntington, Celebrations of Death, 1-130.

17 Pentikäinen, “The Dead Without Status;" Barber, Vampires, Burial and Death.

18 Dunn, The Christianization of the Anglo-Saxons, 101-103. 
cently furnished tomb at Prittlewell, Essex. ${ }^{19}$ The individuals with whom they were buried have tentatively been identified by some historians and archaeologists with Rædwald and Sæberht, two rulers who accepted baptism at Æthelberht’s behest in the early years of the seventh century. ${ }^{20}$ Even if these identifications cannot be proved beyond doubt, we are dealing with very high-status burials dating from around the 620s which demonstrate the way in which elites interpreted Christianity in the earliest conversion period. Coming from a conceptual framework in which religion was equated with the production of good outcomes for individuals and peoples, the spoons and foil crosses (and possibly other objects such as inscribed bowls and a buckle which may have been designed to contain some sort of relic) were understood in the sense of "passports" to a Christian afterlife.

The use of such "passports" in furnished burials indicates a partial or syncretistic understanding of the Christian afterlife. The durable nature of such perceptions and also the difficulties involved making the concept of judgment palatable are both demonstrated by archaeological evidence from the region of eastern Francia which, up to the 530s, had been the Burgundian kingdom. In the fifth century, the Burgundians had originally converted to the Arian (Homoian) form of Christianity; but we can visualise this giving way to a possibly more syncretistic version of the Christian religion after the kingdom was absorbed into Francia. ${ }^{21}$ In the sixth and seventh centuries, some monks and clerics attempted to consolidate Catholic Christianity in the region by creating and distributing - to recipients including clerics and one woman - what were in effect Christian grave goods. ${ }^{22}$ These were buckles, artefacts commonly found in traditional furnished burials: but in this case they were engraved with Biblical motifs, sometimes accompanied by mysterious apotropaic inscriptions. A recurrent theme was Daniel's rescue from the lions' den, an image employed to symbolise the resurrection of the elect to eternal life. The same idea is presented more explicitly on the so-called "Landelinus" buckle, engraved with Revelation's rider on a white horse and the Beast of the Apocalypse. The object declares its own apotropaic power with the Latin inscription "Landelinus made this numen" and also expresses the wish that the possessor may "live a thousand years in the Lord". The rider is represented as a Frankish warrior on a stallion, brandishing a francisca in the one hand and the weapon of the elite, the angon, in the other; the horseman of the Apocalypse is identified with the elite warrior class, while the buckle's owner is putatively classed with those who would be resurrected first to live and reign with Christ a thousand years, before the general resurrection,

19 Dunn, The Christianization of the Anglo-Saxons, 163-164; for analogues of the Prittlewell crosses among the Lombards and Alemanni, see Bierbrauer, "The Cross Goes North."

20 Bede, Historia ecclesiastica, 2.3, 2.15, ed. and trans. Colgrave and Mynors, 142-143, 190-191.

21 Dunn, Belief and Religion in Barbarian Europe, 66-79.

22 For other depictions of Daniel suggesting the resurrection of the elect to eternal life, see Alexander, "Daniel Themes on the Irish High Crosses." 
as described in Revelation 20:4-6. ${ }^{23}$ These buckles, understood as afterlife passports designed to fast-track the deceased to salvation, provide graphic illustration of how far Christian eschatology was - or was not - understood by some members of the elite, including clerics, in the seventh century. The simpler Christian tokens found at Sutton $\mathrm{Hoo}$ and Prittlewell, in kingdoms making a first, limited acquaintance with Christianity suggest a vague understanding of a personal salvation guaranteed by their presence.

So substantial were the differences between Christian teaching and the original intuitions, beliefs and practices of the Anglo-Saxons in these areas that the Church made little or no headway for decades in the area of funerary ritual and must have fallen far short of achieving a full understanding or acceptance of Christian afterlife belief. Even if we accept that the death of baptised Christians was normally followed by Christian funerary ritual in a church (and it is far from certain that this was the case), inhumation of Christians with grave-goods, possibly accompanied by traditional ceremonies at the graveside, continued. Archaeologists have even detected a marked increase in the deposition of grave-goods in female graves in the second quarter of the seventh century. ${ }^{24}$ It seems that traditional beliefs were still sufficiently strong (particularly among women?) for there to be doubts about the adequacy of Christian ritual alone to usher the soul into an otherworld. However, this situation appears to have changed with the abrupt termination of furnished burial throughout Anglo-Saxon England in the period 660-680. ${ }^{25}$

Attempts to attribute this dramatic change solely to the initiative of Theodore of Tarsus, Archbishop of Canterbury between 668 and 690 must founder on the "lack of any specific documentation of Theodore's concern with this matter". ${ }^{26}$ But the disappearance of grave-goods coincides very closely with the period between 664 and 687, which saw the Justinianic Plague sweep England. Bede admits that the plague provoked a reversion in some areas to traditional religious practices. ${ }^{27} \mathrm{~A}$ common folk-aetiology of plague is that it is caused by the spirits of those who die first re-entering their bodies as malevolent revenants and then going on to kill others; and while Bede makes no explicit reference to reversion to non-Christian practices in treatment of the dead, there is possible archaeological evidence of some

23 Treffort, "Vertus prophylactiques et sens eschatologique;" Gaillard de Sémainville, "Nouvel examen de la plaque-boucle mérovingienne de Landelinus découverte à Ladoix-Serrigny;” Young, “The Imagery of Personal Objects;” Dunn, Belief and Religion in Barbarian Europe, 157-161. For afterlife passports, see also Chen, "The Evolution of the Buddhist Other-World Empire” in this volume.

24 Hines and Bayliss, eds., Anglo-Saxon Graves and Grave-Goods of the 6th and 7th Centuries AD, 551-552.

25 Hines and Bayliss, eds., Anglo-Saxon Graves and Grave-Goods of the 6th and 7th Centuries AD, 466; this narrows the timeframe suggested in Blair, The Church in Anglo-Saxon Society, 240, and quoted in Dunn, The Christianization of the Anglo-Saxons, 191.

26 Hines and Bayliss, eds., Anglo-Saxon Graves and Grave-Goods of the 6th and 7th Centuries AD, 553.

27 Bede, Historia ecclesiastica, 3.30, ed. and trans. Colgrave and Mynors, 322-323. 
post-mortem preventative "immobilisations" of the bodies of individuals who could have been regarded as potential revenants. ${ }^{28}$

The spread of the pandemic appears to have galvanised the Anglo-Saxon Church into a more active promotion of Christian funerary ritual and the concept of a Christian interim afterlife than it had been able to attempt or accomplish in previous decades. The 670s saw the emergence of the Dialogues purporting to be written by Gregory I, but probably originating in Northumbria. This work in four books blended some passages taken from Gregory's genuine writings with a large quantity of sermon exempla designed to facilitate or consolidate conversion. The whole of Book Four - together with some individual passages elsewhere in the text - is devoted to questions relating to the interim afterlife and the soul. ${ }^{29}$

While Christianity taught eternal reward or punishment of the reunited body and soul following the Last Judgment, the idea of immediate post-mortem reward or punishment for the souls of the very good or the very bad had long become accepted. The fate of the soul of an individual guilty of relatively minor sins, however, had not been the focus of much detailed consideration before the seventh century: before then, it was variously considered either to sleep, or to exist in suspended animation in the "Bosom of Abraham", or in refrigeria, "places of refreshment" somewhere in the Christian afterlife, awaiting Christ's Second Coming. ${ }^{30}$ However, the Life of Fursey, a text produced on the continent in the 640s describing the out-ofbody experiences of the soul of an Irish monk, announced a major development in interim afterlife concepts when it proposed that penances might be fulfilled in the afterlife. ${ }^{31}$ The Life was vague about where this might occur, but the Dialogues attributed to Gregory I took another major step forward in the development of this Christian interim afterlife by suggesting that this might take place in a nearby location. ${ }^{32}$ Thus the Church now offered a location for souls in the period immediately following death that corresponded to the traditional Anglo-Saxon perception that the souls of the dead existed in spaces in close proximity to the living. ${ }^{33}$ The rapid disappearance of furnished burial argues for the effectiveness of its campaign to persuade the populace that the souls of the dead could safely be transported into

28 Dunn, The Christianization of the Anglo-Saxons, 162-180.

29 For the Dialogues as a work produced in seventh-century England, see Dunn, The Christianization of the Anglo-Saxons, 157-160, and the references given there. The most-cited English translation is that of Zimmerman: Saint Gregory the Great, Dialogues. Neither Moricca, Gregorii Magni Dialogi, nor de Vogüe takes into account all the extant manuscripts and variants of the text: see Yerkes, "An Unnoticed Omission in the Modern Critical Editions of Gregory's 'Dialogues'," and Jeffery, "The Latin Texts Underlying The Old English Gregory's Dialogues and Pastoral Care.”

30 Dunn, The Christianization of the Anglo-Saxons, 13.

31 Dunn, The Christianization of the Anglo-Saxons, 40-42. For the Life of Fursey, see Ciccarese, "Visioni di S. Fursa,” and Transitus Beati Fursei, trans. Rackham.

32 Gregory the Great, Dialogi, 4.42, ed. de Vogüé, trans. Antin, 3:150-153.

33 Semple, "A Fear of the Past." 
this afterlife by Christian funerary rites - an effectiveness "confirmed" by the disappearance of pandemic in the 680s.

If this represented a step forward in the acceptance of Christian afterlife teaching, it also threw into sharp relief the major divergence between Christian and pagan conceptions of the nature of the soul and its relationship with the body. Christianity had inherited a Platonic body-soul duality in which the immortal soul was also the locus of sense-perception, emotion and thought. Analysis of later AngloSaxon literature - Beowulf, The Seafarer, The Wanderer - has revealed that the dominant Old English term for the immaterial part of the person was mod/hyge (the latter a strictly poetical usage), which might be translated as "mind". ${ }^{34}$ A second term, sawul/sawle was also used by the Anglo-Saxons to describe the immaterial part of a person, in this case the immortal or transcendent spirit: its use was restricted to religious discourse and secular contexts involving death, including the latter's possibility or imminence. ${ }^{35}$ But there the similarities between the sawul/sawle and the Christian soul (Latin anima) end. The latter encompassed the mind (mens/animus), apprehension and intellect: but the sawul was endowed with none of these and lay dormant in an uncertain location in the still-living body. For the pagan Anglo-Saxons, not just emotion but also the intellectual and rational qualities would all have been associated with what the later literature calls the mod or hyge, whose seat was in the heart (heort) or upper part of the torso - except on those rare occasions when it might temporarily leave the body in a state of sleep or trance. ${ }^{36}$

Confronted with a folk-taxonomy that did not include a disembodied immortal soul capable of experiencing pain, pleasure or emotion, the Church needed to provide explanations of how the soul could separate from the body at death and nevertheless feel all these things in the interim afterlife. Much of Book Four of the Dialogues is devoted to these issues. Book Three sets the scene, ending with a question posed by Gregory's interlocutor, Peter, about the life of the soul after the death of the body - "which many in the bosom of the Church doubt". ${ }^{37}$ Book Four opens with an explanation of the way in which the living body is moved by a single invisi-

34 Anderson, Folk-Taxonomies in Early English, 327-351; Phillips, "Heart, Mind and Soul in Old English;” Godden, “Anglo-Saxons;” Clemoes, "Mens absentia cogitans in The Seafarer and The Wanderer.” See now also Lockett, Anglo-Saxon Psychologies in the Vernacular and Latin Traditions, and Lockett, "The Limited Role of the Brain in Mental and Emotional Activity According to Anglo-Saxon Medical Learning."

35 Anderson, Folk-Taxonomies in Early English, 334.

36 Anderson, Folk-Taxonomies in Early English, 341.

37 Gregory the Great, Dialogi, 3.38, ed. de Vogüé, 2:432: Quia multos intra sanctae Ecclesiae gremium constituos de vita animae post mortem carnis perpendo dubitare. Quaeso ut debeas, vel quae ex ratione suppetunt, vel si qua animarum exempla animo occurrunt, pro multorum æedificatione dicere, ut hi qui suspicantur, discant cum carne animam non finiri. Dal Santo, Debating the Saints' Cult in the Age of Gregory the Great, argues that the Dialogues were written by Gregory in support of a defence of the cult of saints composed by Eustratius of Constantinople between 582 and 602. There is no evidence whatsoever that Gregory knew of Eustratius's work; and the cult of saints was hardly 
ble soul; ${ }^{38}$ and it further explains that the rational mind is also to be identified with the immortal soul. This latter thesis involved a denial that animals might have any sort of immortal soul, an assertion at variance with the doctrines of Augustine and the authentic views of Gregory himself. ${ }^{39}$ It also necessitated a lengthy excursus in order to deny that scripture (Eccles. 3:18-20) posits any similarity between men and beasts. ${ }^{40}$ Amongst other related questions, Book Four tackles the problem of the soul's ability to experience sensation in the afterlife, arguing that, even though incorporeal, it can suffer punishment by fire in hell. This is said to begin through seeing the flames - in other words through active engagement in obtaining sensation, in the manner of the mod/hyge of the living..$^{41}$ This is not the only instance in the Dialogues of an attempt to encourage belief in the post-mortem Christian anima by depicting it in modes of being or activity normally associated with the mod. Book Two, Chapter 35 is notable for its description of a Christian anima engaged in contemplation of God producing an expansion or relaxation of the "bosom of the mind" (mentis laxatur sinus) and enabling it to see the entire world in the light of God. The relaxed or un-constricted breast, chest, or heart is a characteristic of the roomy or unrestrained mod at the peak of its well-being. ${ }^{42}$ The localisation of the anima throughout the body had already been suggested by the Life of Fursey: when Fursey's out-of-body soul is burned during its visit to the other world, his physical body is found to bear the mark of the burn when the soul is restored to it. Bede's abridged version of the narrative in his Ecclesiastical History omits a good deal of the original, but not these essential points. ${ }^{43}$ Bede also claims to have heard that when Fursey himself recounted his experiences, his listeners noticed that he broke

under threat in the West, as Dal Santo, who seems unaware of recent work on the Dialogues (see note 29 above), attempts to suggest.

38 Gregory the Great, Dialogi, 4.5, ed. de Vogüé, 3:32-39.

39 Gregory the Great, Homilia in Evangelia 29: Bruta vero animalia sunt, vivunt, sentiunt, sed non discernunt, ed. and trans. Étaix, Blanc and Judic, 2:202-203. While Gregory here follows a roughly Augustinian scheme in which souls approximate to the life-spirit and attributes souls - though not higher reason - to animals, later Anglo-Saxon authors either refused to countenance the latter concept (Ælfric), or struggled with this notion (Alfred). See Godden, “Anglo-Saxons.” According to Stanton, "Mimicry, Subjectivity and the Embodied Voice in Anglo-Saxon Bird-Riddles," some of the riddles in the tenth-century Exeter Book imply a degree of animal rationality.

40 Gregory the Great, Dialogi, 4.3-4.4, ed. de Vogüé, 3:22-33

41 Gregory the Great, Dialogi, 4.30, ed. de Vogüé, 3:100: Ignem namque eo ipse patitur et quia concremari se aspecit crematur. On Anglo-Saxon concepts of sense perception see Anderson, Folk-Taxonomies in Early English, 311.

42 Gregory the Great, Dialogi, 2.35.6, ed. de Vogüé, 2:240; Lockett, Anglo-Saxon Psychologies in the Vernacular and Latin Traditions, 106-109.

43 Bede indicates that he is summarising, though he does not list all the areas he omits, which include the pioneering postulation of post-mortem penance as a possibility: Bede, Historia ecclesiastica, 3.19, ed. and trans. Colgrave and Mynors, 272-273. As Bede's later account of Dryhthelm would indicate, discussions about post-mortem penance and purgation had moved on between the 640s and the eighth century. 
out in a sweat, either through terror or joy - a nice additional touch drawing together different conceptions of memory and embodiment. ${ }^{44}$

The Ecclesiastical History presents a further elaboration of the Christian interim afterlife, with its account of the afterlife tour of the soul of a Northumbrian layman, Dryhthelm, who miraculously returns from the dead. ${ }^{45}$ Dryhthelm claimed to have been guided to view the souls of those who had postponed confession of their sins until they were on the point of death alternately tormented by flames and ice in a deep and broad valley of infinite length close to - but distinct from - the fiery pit of hell itself. He is also taken to a very pleasant location described as the abode of blessed spirits. Bede makes Dryhthelm describe the direction he was led in to each location, thus suggesting the topography of a close-at-hand interim afterlife; by the mid-eighth century a re-conceptualised paradise would take shape as a further interim destination for the souls released by masses and prayers from purgative penitential torments. ${ }^{46}$ Bede also carefully stresses the physicality of the torments and pleasures experienced by disembodied souls, especially in the valley where they continually leap between unendurable cold and excruciating heat. ${ }^{47}$ The reality of the sensations experienced by Dryhthelm's own disembodied soul - heat, cold, foul stench, sweet perfumes, intense light - is also highlighted. It is implied that these were hyper-real, surpassing the normal range of bodily feeling. Bede claims that in later life, bitter cold meant nothing to Dryhthelm: "I have", he says, while standing in icy water and alluding to his out-of-body experience, "known it colder". ${ }^{48}$

A vital point in the whole explanatory process relating to the interim afterlife was the invisibility of the Christian soul when it departed the body at the point of death. The anima was endowed with the qualities of intelligence and sense-perception attributed to the mod by the Anglo-Saxons; and one of the most widespread folk-beliefs relating to the mod and to other versions of the body-soul was that it could temporarily exit the body through the mouth in states of sleep or trance in the form of a small animal or bird. ${ }^{49}$ Given the mod-like qualities of the Christian soul, would it not be visible when a person died? This expectation explains the extraordinary discussion of these issues at several points in the Dialogues. ${ }^{50}$ The Dialogues make the claim that the soul's departure is indeed visible - but only to the "eye of

44 Bede, Historia ecclesiastica, 3.19, ed. and trans. Colgrave and Mynors, 274-275: [...] cum sedens in tenui veste vir ita inter dicendum propter magnitudinem memorati timoris vel suavitatis quasi in mediae aestatis caumate sudaverit.

45 Bede, Historia ecclesiastica, 5.12, ed. and trans. Colgrave and Mynors, 488-499. The account's place in Bede's text suggests that the events are supposed to have occurred around the 690s.

46 Bede, Historia ecclesiastica, 5.12, ed. and trans. Colgrave and Mynors, 494-495: beatorum mansiones spirituum. See Kabir, Paradise, Death and Doomsday, esp. 77-110.

47 Bede, Historia ecclesiastica, 5.12, ed. and trans. Colgrave and Mynors, 488-493.

48 Bede, Historia ecclesiastica, 5.12, ed. and trans. Colgrave and Mynors, 498-99.

49 See Dunn, The Christianization of the Anglo-Saxons, 170; Bremmer, The Early Greek Concept of the Soul.

50 Gregory the Great, Dialogi, 2.35.6, 4.11.8, ed. de Vogüé, 2:240, 3:48-49. 
the mind" of sufficiently spiritual and prayerful individuals. ${ }^{51}$ But the discussion then vacillates between not describing the form taken by the soul (though it may ascend to heaven in a globe of fire) and giving it the form of a bird: the departing soul of Abbot Spes of Campli takes the shape of a dove..$^{52}$ This trope appears in modified form in the Life of Gregory the Great composed by an anonymous member of the monastic community of Whitby in the early eighth century. Its description of the death of the Northumbrian Bishop Paulinus suggests that his soul was also seen again only by some - flying toward heaven, this time in the form of a white swan. To signify that the Christian anima was not simply immortal, but also capable of intelligence and sensation, the Dialogues and the Whitby Life both show that it was necessary to evoke the mod, popularly intuited as encompassing these qualities.

While it is clear that there were considerable problems in presenting Christian eschatology and apocalyptic to a non-ecclesiastical audience, one source has sometimes been read to suggest that the Anglo-Saxon Church sought to teach the Apocalypse of John to monks and laity alike in the late seventh century. This is Bede's own history of the abbots of Wearmouth-Jarrow, which describes how, in 679/80, Benedict Biscop returned from a visit to Rome with pictures for the monastery church at Wearmouth, bringing with him

[...] paintings of holy images to decorate the church of the blessed apostle Peter which he had built: there was an image of Mary, the blessed Mother of God and virgin forever, together with the twelve apostles, with which he enriched the middle apse of the church; the painted boards stretched from one wall to the other. There were images of the gospel stories with which he adorned the south wall of the church; and images of the visions of the Apocalypse of the blessed John with which he similarly decorated the north wall. ${ }^{53}$

Biscop's church decorations have not survived. One suggestion is that they were panels specifically commissioned for the comparatively restricted space available in the tall and narrow aisles of St Peter's Wearmouth; another - and more convincing

51 Gregory the Great, Dialogi, 4.11.7, ed. de Vogüé, 3:40-41: Nam multi nostrorum, mentis oculum fide pura et uberi oratione mundantes, egredientes a carne animas frequenter viderunt.

52 Vita Gregorii, 17; The Earliest Life of Gregory the Great, ed. and trans. Colgrave, 101.

53 Bede, Historia abbatum, 6; Bede, "History of the Abbots of Wearmouth and Jarrow," ed. and trans. Grocock and Wood, 36-37: [...] picturas imaginum sanctarum quas ad ornandam ecclesiae beati Petri apostoli, quam construxerat, detulit: imaginem videlicet beatae Dei genetricis semperque virginis Mariae, simul et duodecim apostolorum, quibus eiusdem ecclesiae testudinem ducto a pariete ad parietem tabulato praecingeret; imagines evangelicae historiae quibus australem parietem decoraret; imagines visionum apocalypsis beati Iohannis, quibus septentrionalem aeque parietem ornaret [...]. In Roman and Italian churches the Apocalypse of John was depicted in a highly selective fashion, featuring themes such as the four living creatures; the seven-sealed scroll and the seven candlesticks; a roundel, whose colours evoke the "rainbow that looked like an emerald" (Rev. 4:7) enclosing a throne with the cross and the Lamb of God. See Herrmann and van den Hoek, "Apocalyptic Themes in the Monumental and Minor Art of Early Christianity." Chazelle, "Art and Reverence in Bede's Churches at Wearmouth and Jarrow," 89, suggests that the Wearmouth representations might have included a Christ in Majesty analogous to the one in the Codex Amiatinus. 
- hypothesis is that he imported not only icons but representations in a variety of media such as ivory, metal or textiles. ${ }^{54}$ Bede claims that his intention

[...] was that all who came into the church, even those who did not know how to read, should always gaze on the lovely sight of Christ and his saints wherever they looked, albeit in a picture; they should either recall with a keener mind the grace of the Lord's incarnation, or remember to examine themselves more closely, seeing the decisive nature of the Last Judgment as though they had it before their very eyes. ${ }^{55}$

However, we should resist attempts to read a broad pastoral significance into Biscop's imported images. ${ }^{56}$ They were brought to Wearmouth at a time of extraordinarily intense theological and liturgical contact between Rome and Northumbria, in the wake of the Monothelite Controversy which had convulsed the Church for decades; their selection underlined the community's position as a centre of Roman liturgy and affirmed its Chalcedonian orthodoxy. ${ }^{57}$ Bede's later suggestion of the instructive aspects of Biscop's pictorial imports, including those based on the visions of Revelation, seems to have developed out of his own monastic education in Wearmouth: as a young nutritus still unable to read properly, he may himself have been taught through their use. ${ }^{58}$ His words also reflect awareness of Gregory I's letters to Bishop Serenus of Marseilles in support of the use of pictures in churches as a means of instruction for the illiterate. ${ }^{59}$ But Biscop's decorative programme was designed to resonate with members of a monastic community, and it is revealing that Bede's description of the Apocalypse pictures partners examen or test (in the sense of the trials of the Last Judgment) with se ipsi examinare - to examine one's self, a part of the monastic process of meditation and penance. Perhaps it was the influence of Biscop's pictures on the young Bede's education that would later inspire him to decide on a commentary on John's Apocalypse as his first venture into scriptural exegesis. ${ }^{60}$

54 Meyvaert, "Bede and the Church Paintings;" Chazelle, "Art and Reverence in Bede’s Churches at Wearmouth and Jarrow;" 86.

55 Bede, Historia abbatum, 6, ed. and trans. Grocock and Wood, 36-37: [...] quatinus intrantes ecclesiam omnes etiam litterarum ignari, quaquaversum intenderent, vel semper amabilem Christi sanctorumque eius, quamuis in imagine, contemplarentur aspectum; vel dominicae incarnationis gratiam vigilantiore mente recolerent, vel extremi discrimen examinis, quasi coram oculis habentes, districtius se ipsi examinare meminissent.

56 Peter Darby, Bede and the End of Time, 2, states that Bede "clearly considered the pictures to be valuable tools in the education of the illiterate"; although he then adds, more appositely, that Bede "would first have gazed upon them as a child before he was literate himself". See also Darby, "Bede, Iconoclasm and the Temple of Solomon."

57 Chazelle, "Art and Reverence in Bede's Churches at Wearmouth and Jarrow," 89-90.

58 Darby, Bede and the End of Time, 2.

59 Chazelle, "Art and Reverence in Bede's Churches at Wearmouth and Jarrow," 91.

60 Discussed by Wallis, Bede: Commentary on Revelation, 35. 
Elsewhere in Northumbria, the monumental open-air crosses at Bewcastle and Ruthwell, dating from the period c. 700-750, reveal that the message of Christianity was still being finessed with elite values and expectations, which did not necessarily include the idea of judgment or at least its unpleasant corollary, eternal damnation. ${ }^{61}$ One interpretation of the Bewcastle Cross suggests that it was made for a noble family, represented by the figure of a man with a hawk carved near its base and also by individuals commemorated in some of its worn runic inscriptions. ${ }^{62}$ It associates them not just with salvation through the death of Christ, the latter signified by the image of Christ recognised by two beasts, but also, in its representation of John the Baptist holding the Agnus Dei, the final triumph of Christ as Lord of Lords and King of Kings, as in Revelation 17:14. A similar message may be conveyed by a further image of Christ with the closed scroll of the Book of Life in his left hand, while his right hand is raised in blessing - a gesture implying that the depicted individual and those named in the runes are inscribed in the Liber Vitae of Revelation 20:12-15 and will therefore be saved..$^{63}$ Although the extensive knowledge of Christian liturgy and scripture encoded in the cross's imagery tends to confirm the suggestion that it was made for a religious establishment, its runes identify it as a sigbecn or sign of victory: and it is hard to escape the conclusion that this victory focused on the automatic promise of eternal life with Christ in heaven for the kin group associated with it. The Ruthwell Cross, also putatively associated with a religious establishment, though (as far as we can tell) not with any named individual or family, similarly seeks to align Christianity with elite values. It includes a runic inscription in the form of a poem presenting the death of Christ in terms of the death of a warrior-hero, employing the vocabulary of traditional anthropology which makes him modig - full of mod, courageous. At the same time, it alludes to the Monothelite Controversy: God Almighty wills to mount the cross. ${ }^{64}$ Its multivalent imagery offers a dense web of monastic allusions interwoven with references to Roman stational liturgy, to the Eucharist, Annunciation, Lent, Easter, conversion and baptism. ${ }^{65}$ As on the Bewcastle Cross, a representation of Christ Over the Beasts leads to another featuring John the Baptist bearing the Agnus Dei. While the Latin inscription around the former refers to Christ as the "judge of fairness" (iudex aequitatis), this relates to "beasts and dragons in the desert" who acknowledge the saviour of the world and in doing so are converted from evil to good: and Christ holds the scroll of a prophet, a possible reference to the Book of Life. ${ }^{66}$ Once again there is an implication of guaranteed salvation for those associated with the cross.

\footnotetext{
61 Ó Carragáin, "Christian Inculturation in Eighth-Century Northumbria."

62 On the dangers of over-interpreting the runic inscriptions, see Page, "The Bewcastle Cross."

63 Karkov, "The Bewcastle Cross," 19-20; Ó Carragáin, "Christian Inculturation in Eighth-Century Northumbria."

64 Ó Carragáin, "The Ruthwell Crucifixion Poem in its Iconographic and Liturgical Contexts."

65 See Ó Carragáin, Ritual and the Rood.

66 Ó Carragáin, Ritual and the Rood, 150-153, 201-208.
} 
A more problematic issue for the Anglo-Saxon Church, and one that may have contributed in a different way to the postponement of full consideration of the Last Judgment, was the related question of the afterlife fate of pagan ancestors. For the Anglo-Saxons as for other Germanic peoples the ties of kinship did not cease on death: the kin group extended below as well as above the ground. ${ }^{67}$ Were the ancestors not to be saved as well? The issues involved in conversion are famously encapsulated in the tale of the failed baptism of Radbod, leader of the Frisians in the early eighth century. He is said to have turned away from the font on the very point of baptism, when Bishop Wulfram of Sens tactlessly informed him that his non-baptised ancestors were damned. Although its authenticity has been contested in the past, recent research vindicates it as a narrative intended to elucidate a real and enduring problem. Radbod is presented as refusing to go "without the company of his predecessors, the princes of the Frisians, to reside with a small number of the poor in the celestial kingdom". ${ }^{68}$

The problem of the non-Christian ancestors had already been recognised by churchmen involved in earlier stages of the Germanic conversions. Some early Christian writers had taught that, between his death and resurrection, Christ had descended into hell and converted or baptised all those who had lived before his coming. ${ }^{69}$ This laid the ground for the so-called "Dated Creed" of 359, created not only to resolve the Trinitarian controversies of the fourth century but also to address the intuitions and beliefs of the pagan Goths on the Danubian border: it indicated that Christ had descended into hell to rescue some of its inhabitants. ${ }^{70}$ The idea that Christ had baptised those who lived and died before him not only meant salvation for some pagan ancestors, but might also be taken to imply its possibility for all who had died ignorant of the Christian message. The doctrine of Christ's Descent into hell was repeated more briefly in the Creed of Constantinople of 360 and also passed into some versions of the Apostles' Creed, where the laconic phrase descendit ad inferos or ad infera might have evoked a more vivid picture in the minds of hearers and perhaps even formed the basis of homilies in which clerics encouraged

67 Boyer, Religion Explained, 237-241; Pentikäinen, "The Dead without Status;" Williams, "Monuments and the Past in Early Anglo-Saxon England;” Dunn, The Christianization of the Anglo-Saxons, 18, 91-92.

68 The most recent discussion is in Meens, "With One Foot in the Font." Thanks to Immo Warntjes for this reference.

69 Notably Clement of Alexandria and Origen. See Rambaran-Olm, John the Baptist's Prayer or the Descent into Hell from the Exeter Book, 179-196, for a list of references to the doctrine of the Descensus in post-Apostolic and medieval commentators up to the end of eleventh century; also MacCulloch, Comparative Study of an Early Christian Doctrine.

70 Dunn, "Intuiting Gods," and Dunn, Belief and Religion in Barbarian Europe, 31-39; Hanson, Search for the Christian Doctrine, 364. Mansi, Sacrorum Conciliorum Nova et Amplissima Collectio, 294: [...] ubi omni dispensationis adimplevisset, secundum Patris voluntatem, crucifixum et mortuum esse, et at inferos descendisse, atque ibi, quod sui officii erat peregisse; quem janitores infernorum conspiciati exhorrurerunt [...]. 
them to think that their ancestors might be saved. ${ }^{71}$ However, there was no agreement in the Church on the effects of Christ's Descent: the version of the Apostles' Creed used in Rome from at least the fifth century onwards did not include the Descent clause and Gregory I considered that Christ had liberated only the righteous, the prophets and patriarchs. ${ }^{72}$

The Anglo-Saxon Church appears to have been deeply divided on the whole issue. A version of the Apostles' Creed without the Descent was added to the Codex Laudianus version of Acts: this is a manuscript possibly used by Bede himself and taken from England to Fulda in the eighth century by the West Saxon missionary Boniface, who represents a section of the Anglo-Saxon Church which took a hard line where the salvation of pagan ancestors was concerned. ${ }^{73}$ At a church council in Rome in 745, he played a leading role in condemning Clemens, an Irish missionary in Austrasia, on the grounds that "contrary to the teaching of the Fathers, he affirms that Christ descended into hell to deliver all those, believers and unbelievers, servants of Christ as well as worshippers of idols, who were confined there."74

The Radbod story may have been composed in response to Clemens's activities, to support the rejection of any possibility of ancestor salvation and to underline the necessity of baptism. ${ }^{75}$ Earlier, the Dialogues attributed to Gregory the Great had specifically rejected the idea of prayer for deceased infidels and godless people. ${ }^{76}$ By contrast, Willibrord, a contemporary of Boniface's, who like him worked among the Frisians, seems to represent a group in the English Church conscious of the need for a more assimilative approach. ${ }^{77}$ Willibrord had spent ten years in Ireland, the homeland of Clemens, where the idea of the "naturally" virtuous pagan of earlier times had developed. ${ }^{78} \mathrm{~A}$ native Northumbrian, he would also have been familiar with the Anonymous of Whitby's Life of Pope Gregory, which includes the story of how the pope posthumously baptised the Roman Emperor Trajan "by his tears", when he wept on being told how this dead pagan had performed a notably charita-

71 Owen, The Vision of Hell, 94-95.

72 See Rambaran-Olm, John the Baptist's Prayer or the Descent into Hell from the Exeter Book; Owen, The Vision of Hell, 94-95. Rufinus, Commentarius in symbolum Apostolorum, 18, notes that, "He descended into Hell' is not added in the Creed of the Roman Church, neither is it in that of the Oriental Churches. It seems to be implied, however, when it is said that 'He was buried'." Rufinus, On the Creed, trans. Fremantle, 550; Badcock, History of the Creeds, 145-147.

73 Walther, “Codex Laudianus G 35," 1:1-5, 13-20.

74 Letters of Saint Boniface, ed. Emerton, 102.

75 Meens, "With One Foot in the Font," 589.

76 Gregory the Great, Dialogi, 4.46.8, ed. de Vogüé, 3:164-165. A sermon probably originating in Anglo-Saxon England suggests that some hard-line clerics tried to face down hostile comments about the tardy arrival of Christ as Saviour, which logically denied salvation to many: Machielsen, “Fragments patristiques non-identifiés du Ms. Vat. Pal. 577,” 535.

77 Meens, "With One Foot in the Font," 589-593.

78 See Ó hÓgáin, The Sacred Isle, 190; Ireland, "Some Irish Characteristics of the Whitby Life of Gregory the Great,” 153-159. 
ble deed..$^{79}$ This tale, echoed in the legend of St Erkenwald, was designed to offer some degree of reassurance to anyone concerned about the possibility of eternal separation from the ancestors in the Christian afterlife. ${ }^{80}$

One tactic employed on the continent to "Christianise" pagan ancestors retrospectively, re-establishing the bonds of kin both above and below ground, had involved the building of churches over their graves. ${ }^{81}$ In England, the late seventhcentury penitential known as the Discipulus Umbrensium forbade both re-burial of pagans in consecrated ground and also the construction of churches over their tombs. ${ }^{82}$ We have no way of knowing how rigorously these prohibitions were enforced throughout England after this period; but the continued importance of the issue of the ancestors is highlighted by the depiction of Christ's Descent into hell on the Wirksworth Slab, a carved tomb-cover from late eighth- or early ninth-century Mercia. ${ }^{83}$

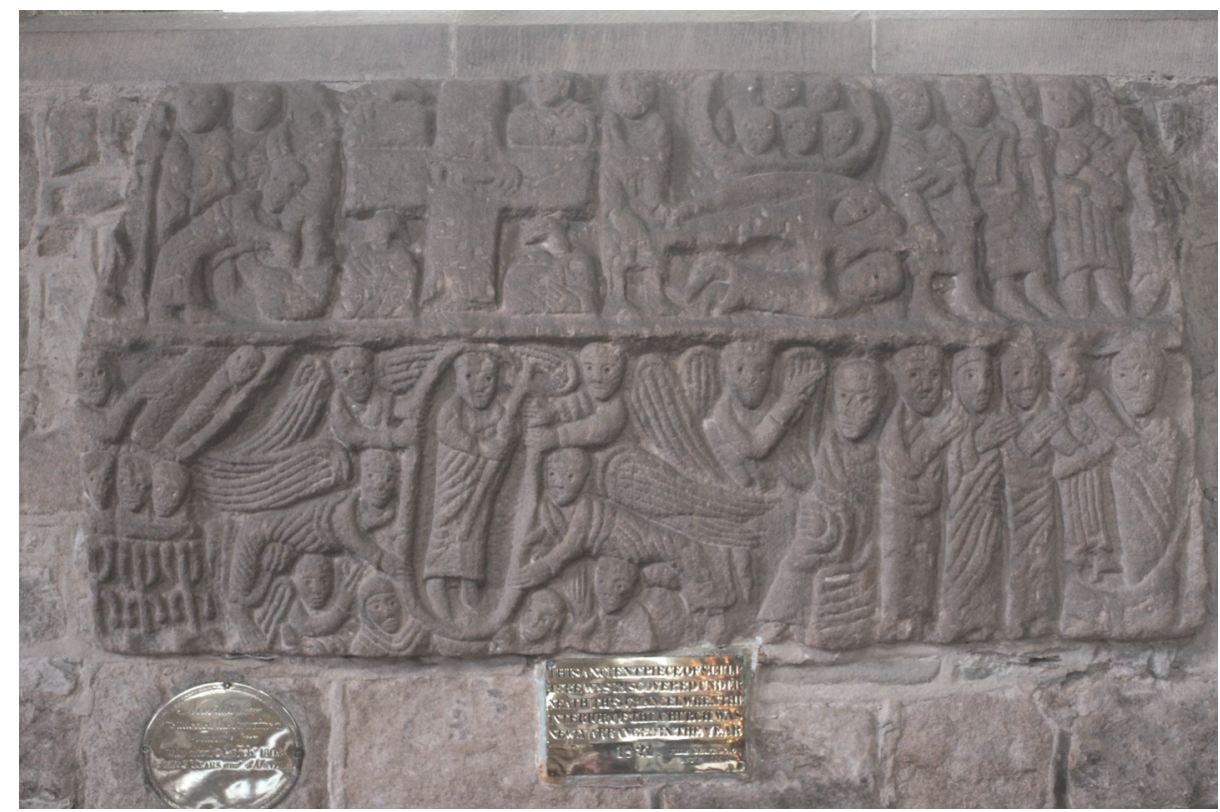

Fig. 1: Wirksworth Slab, general (Photo: Marilyn Dunn)

79 Vita Gregorii, 29, ed. and trans. Colgrave, 128-129.

80 Vita Gregorii, ed. and trans. Colgrave, 161-163, note 22.

81 See Geary, "The Uses of Archaeological Sources for Religious and Cultural History,” 36-38.

82 Paenitentiale Theodori, 2.1.4-5; ed. Finsterwalder, 312.

83 Hawkes, "Wirksworth Slab.” I offer a different interpretation of the overall significance of the Slab. 
Jane Hawkes suggests that it should be associated with an elite ecclesiastical foundation, possibly a double house or a monastery founded by a woman. The righthand side of the slab is devoted to the Marian feasts of Annunciation, Presentation or Purification, Dormition and Assumption. ${ }^{84}$ On the left are four scenes representing Easter: Christ washing the feet of the Apostles; a cross, symbol of the crucifixion; Christ's Descent into hell and the resurrection. ${ }^{85}$ The scenes show the influence of earlier and eastern iconographic models and also eastern apocrypha, adapted to specific ends: Christ's Ascension is witnessed, unusually, by two women, one of whom probably signifies the person originally buried under the slab. As at Bewcastle and Ruthwell, the anticipation of salvation rather than judgment is conveyed, in this case by the cross bearing the Agnus Victor and surrounded by the symbols of the Evangelists. This is the Lamb of Revelation 17:14, with whom the chosen and faithful are associated. And implied salvation is also extended to non-Christian ancestors.

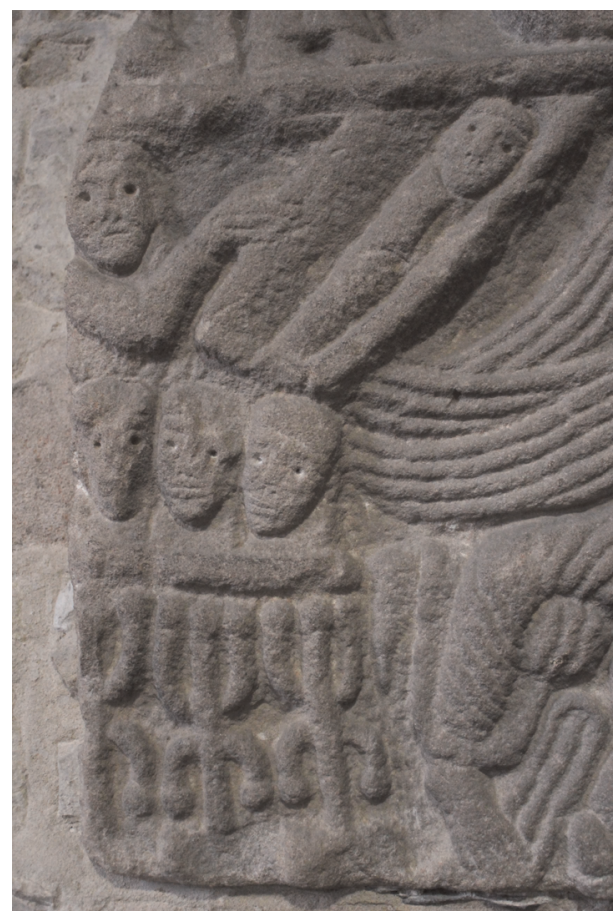

Fig. 2: Wirksworth Slab, detail (Photo: Marilyn Dunn)

84 Clayton, The Cult of the Virgin Mary in Anglo-Saxon England, 25-51, for the introduction of the Marian feasts of Presentation, Annunciation, Nativity and Dormition into Anglo-Saxon England. See also Clayton, The Apocryphal Gospels of Mary in Anglo-Saxon England, 101-107.

85 Harbison, “Two Panels On The Wirksworth Slab," suggests, unconvincingly, that the descensus is the nativity and washing of the infant Christ and identifies the presentation as the adoration of the Magi. 
The depiction of the Descent itself favours a maximalist interpretation of Christ's activity in hell. It shows him reaching into an open coffin to deliver the swathed Adam who lies there: underneath are three figures in a brazier, representing Herod, Cain and Judas, the only inhabitants left in hell, according to the apocryphal Coptic Resurrection of Bartholomew, after Christ's visit. ${ }^{86}$ As a whole, the Wirksworth Slab indicates an elegant solution to the problem of the ancestors: the person buried under this carving proclaimed not just her own personal salvation, but also of that of her illustrious forebears.

Monuments such as the Ruthwell and Bewcastle Crosses and the Wirksworth Slab conveyed their implication of guaranteed salvation through linking Christ's redemptive sacrifice on the Cross with allusions to a restricted number of texts from Revelation which associate salvation with kingship, lordship, victory and being part of an elect. This selective approach not only circumvented discussion of the highly unattractive possibility of eternal damnation but also conveniently avoided the awkward question of when and in what circumstances the Last Judgment might occur. Its association with the end of the present world, a subject heavily freighted with non-Christian resonances, may have been another factor contributing to the deferment of full consideration of its meaning. While the Church's calendar incorporated cyclical features, such as Christmas, Easter and saints' days, effectively absorbing midwinter, spring and other non-Christian celebrations, ${ }^{87}$ the Christian view of time and eternity begins with God's creation of the world and stretches into eternity when, after the Parousia and Last Judgment, the present world will pass away and there will be a new heaven and a new earth. ${ }^{88}$ This linear view of time and the end of the world, in which the Final Judgment plays a key role, was not shared by the pagan Anglo-Saxons. Clive Tolley has shown that a narrative in Bede's Ecclesiastical History, in which a house-pillar survives an otherwise all-consuming fire, points to the existence of an alternative non-Christian eschatology in which the world ends in a cosmic conflagration. This was part of a cyclical process, also involving the world's renewal and re-population, beginning with the two human beings who survive the cosmic disaster. ${ }^{89}$ So Pope Gregory's insistence in his letter to Æthelberht on the approach of the "end of the world" may have unintentionally evoked images and ideas very different from those he wished to suggest. The enduring potency of this competing eschatology is suggested by Bede's attempts to defuse the myth of cosmic cyclicality, when he attributes the house-pillar's survival to a miracle worked by a relic of the blood of King Oswald of Northum-

86 Cockerton, "The Wirksworth Slab," 11-12; Elliott, The Apocryphal New Testament, 668-672. Hawkes, "Wirksworth Slab," 256, questions the identification of the three figures, but also stresses the scene's dependence on very early models.

87 Dunn, The Christianization of the Anglo-Saxons, 152-154.

88 See Gurevich, Categories of Medieval Culture, 25-39, 93-151.

89 Tolley, “Oswald’s Tree.” 
bria. It may also underlie the remarkable concern with time and eternity which led Bede to revise his first work on the subject, De temporibus ("On Times"), composed in 703, with the production of the much longer De temporum ratione ("On the Reckoning of Time") in 726. In the latter, Bede warned against any speculation about the imminence or otherwise of the Second Coming. He also added a seventh and eighth age to the six ages of his earlier De temporibus. The seventh age runs parallel with the sixth and is the time spent by the souls in the interim afterlife. The eighth world age commences with the Last Judgment and stretches on into what Bede terms in its conclusion "eternal stability and stable eternity". ${ }^{90}$ His concern to establish the linearity of Christian time may also have prompted the Ecclesiastical History's extensive use of Anno Domini dating. This last development tends to be understood primarily in the context of Bede's use of Dionysius Exiguus's Easter tables, which came with an Anno Domini chronology attached. ${ }^{91}$ But while Dionysius's tables were known elsewhere, Bede was the first to attempt to popularise Anno Domini dating, which had the advantage of establishing a clearly linear view of past, present and future, at the same time as making overt reference to the Incarnation. By the last quarter of the eighth century, this was becoming more commonly used in AngloSaxon charters and became a normal feature of them in the ninth; the 816 synod of Chelsea decreed that the year of the Incarnation should always be used in episcopal documents. $^{92}$

Such promotion of the concept of Christian linear time represents an important step forward in allowing the Anglo-Saxon Church to draw the attention of the laity to the Last Judgment as judgment. One of the first indications of this is to be found on a small ivory plaque now housed in the Victoria and Albert Museum, depicting the general resurrection of the dead, Christ as judge and the entry of the good and wicked to heaven and hell. Opinions as to its date vary widely, but Jane Hawkes believes that it was created in England around 800. ${ }^{93}$

\footnotetext{
90 Bede, De temporibus liber, ed. Jones; Bede, De temporum ratione, ed. Jones. English translations with commentaries: De temporibus: Bede, Nature of Things and On Times, trans. Kendal and Wallis. De temporum ratione is translated in Bede, Reckoning of Time, trans. Wallis. See also Darby, Bede and the End of Time; Palmer, "The Ends and Futures of Bede's De temporum ratione."

91 For example, Declercq, Anno Domini, 155-159.

92 Declercq, Anno Domini, 169.

93 Hawkes, "The Road to Hell," 233. She adds that if it is not actually Anglo-Saxon, it comes from a centre with close connections to Anglo-Saxon England. Michelli, "Beckwith Revisited," argues for a date in the first half of the eleventh century. See also Brenk, Tradition und Neuerung in der christlichen Kunst des ersten Jahrtausends, 118-120.
} 


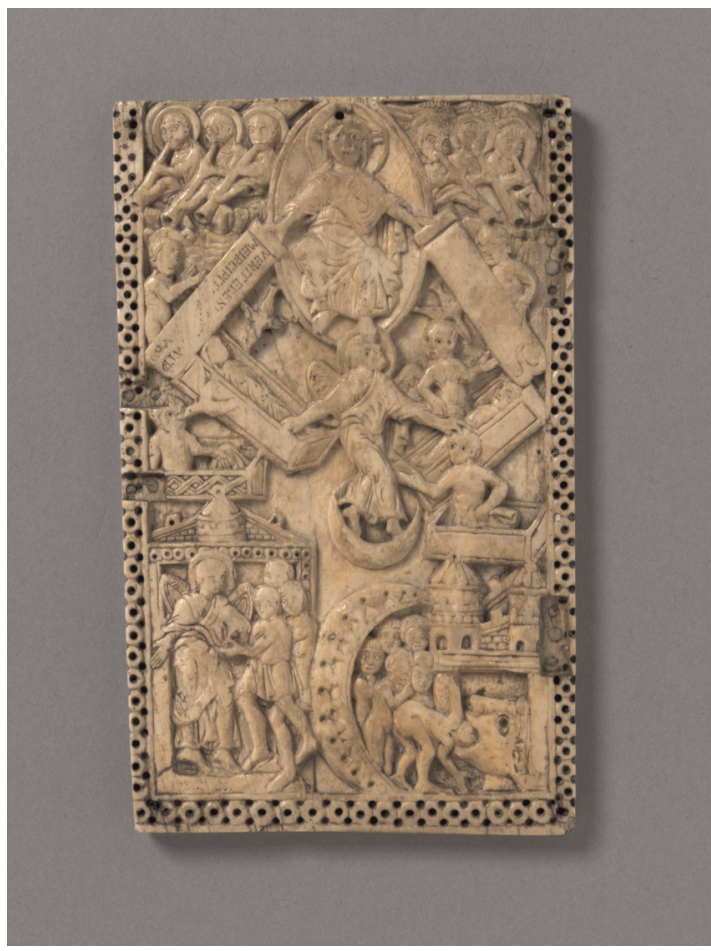

Fig. 3: Victoria and Albert Ivory (C Victoria and Albert Museum)

One of the two scrolls held by the Christ-judge quotes from the "Little Apocalypse" of Matthew 25:34 (in a pre-Vulgate version): Venite benediciti patris mei percipite regnum vobis ("Come, ye blessed of my Father, inherit the kingdom prepared for you”). Hawkes thinks the other scroll is worn and would have quoted Matthew 25:41 ("Depart from me, ye cursed into everlasting fire I know you not"). Many details of the scene remain to be elucidated: for example, the central figure might be the Archangel Michael, but this interpretation may rest on Michael's depiction in a similar central position in later Last Judgment representations. There is a possible reference to the cityscapes of Jerusalem and Bethlehem as depicted in the mosaics of Santa Maria Maggiore, Rome, in the buildings of heaven and hell into which the resurrected bodies are received. However, the sinners file into the earliest known example of a distinctively English phenomenon - the Hell Mouth. More than one scholar has suggested that its origins lie in the northern pagan myths of the end of the world, known to us through later Norse literature, featuring the devouring wolf, Fenrir, who plays an important role in a cosmic destruction-and-renewal myth. ${ }^{94}$ An

94 Pluskowski, “Apocalyptic Monsters,” 160; Schmidt, The Iconography of the Mouth of Hell, 28, 64; Schapiro, "Cain's Jaw-Bone that Did the First Murder," n. 66. All draw attention to the later Viking- 
earlier version of the myth may have circulated in Anglo-Saxon England: another devouring Hell Mouth appears on the mid-ninth-century cross-shaft at Repton (then in Mercia). ${ }^{95}$ These images suggest that traditional understandings of the nature of time and the end of the world have now been re-inscribed in a Christian version of time, judgment and afterlife. On the other hand, the ivory also suggests that the Church was still obliged to evoke traditional perceptions when trying to represent the Christian soul. The carving features the resurrection of the flesh, a doctrine which not only proved challenging for theologians but often provoked scepticism amongst ordinary folk or potential converts: nevertheless, in conformity with the theology of Augustine, the ivory shows fully formed human bodies rising from their coffins or sarcophagi. ${ }^{96}$ However, the carver also represents the moment at which resurrected bodies are re-united with souls by picturing the latter as birds, one of which flies into the mouth of a body rising from a sarcophagus. This striking image indicates that even in the context of a full consideration of the Last Judgment to come, it was still necessary to refer to deep-seated intuitions in order to suggest the Christian conception of the disembodied soul. ${ }^{97}$

Further evidence of the Anglo-Saxon Church's growing confidence in foregrounding judgment and in particular the potentially rebarbative doctrine of damnation can be found on the late eighth-century outdoor cross from Rothbury in Northumbria. Insofar as we can tell from its present fragmentary condition, Rothbury depicted the Crucifixion; Christ in Majesty; the Raising of Lazarus (which we might interpret as reference to Christ's power to raise bodies from the dead and therefore to the resurrection of the body); and a crowd either welcoming Christ into Jerusalem or "adoring the cross in a general apocalyptic scheme". ${ }^{98}$ One panel appears to combine Christ's Ascension with visual references to the Second Coming, using elements derived from the traditional Roman depiction of the synoptic Gospels' version of the Last Judgment, which shows Christ in clouds. ${ }^{99}$ Such traditional Roman approaches to the Last Judgment had presented the Second Coming

era crosses at Gosforth and on the Isle of Man, where depictions of Fenrir represent a similar reinscription of non-Christian intuitions in the context of the Christian message.

95 Hawkes, “The Road to Hell,” 235.

96 Bynum, The Resurrection of the Body in Western Christianity, 98-99.

97 A similar understanding may explain Irish representations of the Resurrection depicting a bird entering Christ's mouth as he lies in the tomb, such as on the "Cross of the Scriptures" at Monasterboice and the Durrow Cross: Harbison, The High Crosses of Ireland, vol. 1, catalogue nos. 54 and 89; vol. 2, figs. 140 and 254; Beckwith, Ivory Carvings in Early Medieval England, 22. For the persistence of body-soul intuitions at variance with Christian doctrine, see the items by Godden and Lockett at note 34, above, and Thompson, Dying and Death in Later Anglo-Saxon England, 49-50.

98 Hawkes, “The Rothbury Cross,” 88.

99 See Herrmann and van den Hoek, "Apocalyptic Themes in the Monumental and Minor Art of Early Christianity," 59-61 for the sixth-century decoration of SS Cosmas and Damian and also for images inspired by Revelation in the same church. Hawkes, "The Rothbury Cross," 91, suggests that Monkwearmouth could have provided direct inspiration for Rothbury. 
in a manner "intended to provide the viewer with gratification and freedom from anxiety". ${ }^{100}$ Jane Hawkes notes several apocalyptic features of the Rothbury Ascension panel and underlines the fact that its models "showed Christ as judge with the company of heaven, but did not include the damned in hell". ${ }^{101}$

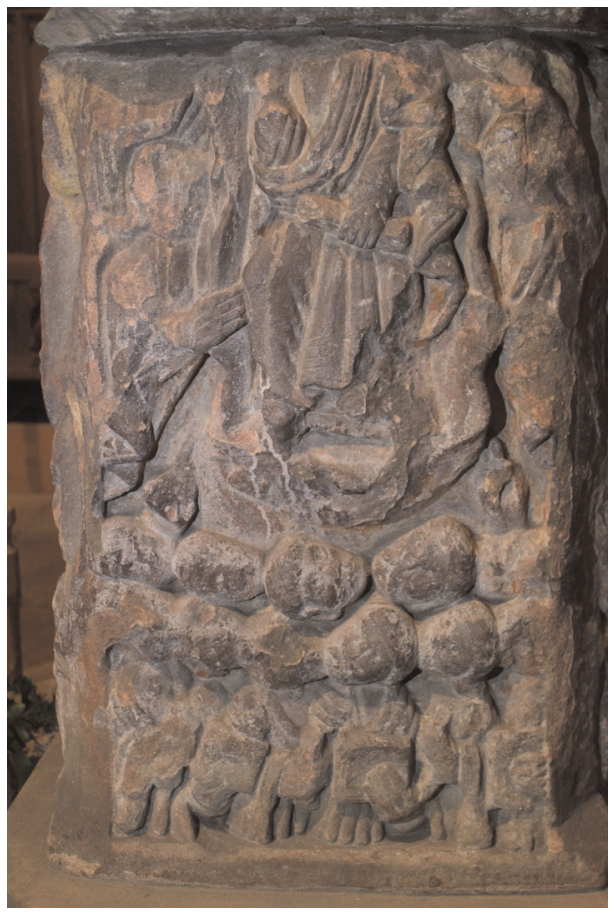

Fig. 4: Rothbury Cross Ascension (Photo: Marilyn Dunn)

The significance of the Rothbury Cross lies in its departure from its Roman models by the addition of another carved panel which, according to current interpretations, does depict the damned in hell.

On this side, grotesque naked and deformed humanoid figures are suspended within the intertwining bodies of serpent-like beasts that menace their heads and genitals. ${ }^{102}$ Rothbury thus encapsulates what we might call a remarkable "bodily turn" in the depiction of the Last Judgment by its creation of an explicit and horrific picture of the reality of hell in which the re-united bodies and souls of sinners are tortured for eternity. The novelty of the depiction is underlined by the way in which

100 Herrmann and van den Hoek, "Apocalyptic Themes in the Monumental and Minor Art of Early Christianity," 80.

101 Hawkes, “The Road to Hell," 237.

102 Hawkes, "The Rothbury Cross," 88. 
the Ascension scene builds on traditional imagery, while the sculptors evidently had to improvise their own visual language to represent the torments of the damned: the threatening reptilian beasts appear to derive their form from zoomorphic motifs current in Insular art. ${ }^{103}$

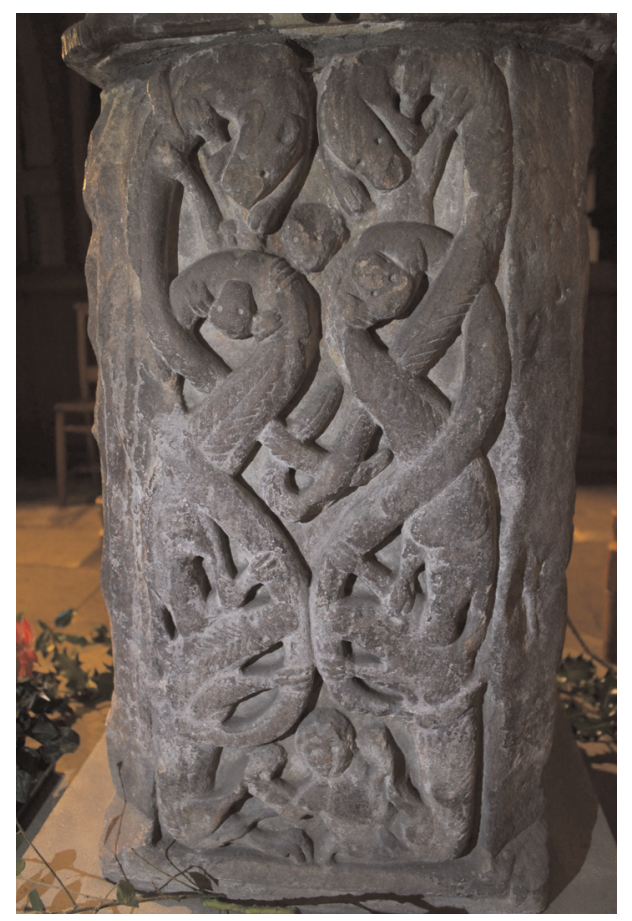

Fig. 5: Rothbury Cross Dammed (Photo: Marilyn Dunn)

The Victoria and Albert Ivory and the Rothbury Cross seem to mark the first moves in the direction of the elaborate Last Judgments carved above church doorways or in paintings and mosaics in church interiors from the central Middle Ages onwards, with their positioning of saints and sinners on Christ's right and left and their remarkably imaginative depictions of the torments of the damned and, in some cases, the Mouth of Hell. But tentative steps in this direction had come about as a result of a long period of interaction and assimilation between Christianity and the original beliefs of the Anglo-Saxons. The Anglo-Saxon Church found itself obliged to make many adjustments and accommodations in order to deal with peoples whose idea of religion was focused on personal or familial benefit; whose understanding of the way body and soul were constituted was at odds with Christian teaching; who num-

103 Hawkes, “Art of Damnation in Anglo-Saxon Sculpture,” 237; Hawkes, "The Rothbury Cross," 88. 
bered the dead as an important part of their kin-group; and who viewed time and eternity in cyclical terms. All this contributed to deferring and delaying consideration of the Last Judgment - itself a difficult issue in the first place, as the Anglo-Saxons did not think in terms of an afterlife encompassing post-mortem judgment or differentiated outcomes. While Pope Gregory had initially been eager to preach apocalyptic to Æthelberht of Kent, it did not appear in his subsequent instructions to his mission once he was slightly better informed about the religion of the pagan Anglo-Saxons. Instead, Gregory recognised the need to begin work with what little mutual ground he could identify, specifically the customs of religious feasts and festivals, between the Church and its target populations. "The man who is attempting to climb to the highest places", he decided, "rises by steps and degrees and not by leaps" - an aphorism that would prove all too accurate in the area of Christian apocalyptic. ${ }^{104}$

\section{Bibliography}

\section{Abbreviations}

CCSL Corpus Christianorum Series Latina. Turnhout: Brepols, 1953-.

SC Sources Chrétiennes. Paris: Édition du Cerf, 1941-.

\section{Primary Sources}

Bede. Commentary on Revelation. Translated by Faith Wallis. Liverpool: Liverpool University Press, 2013.

Bede. Historia abbatum ("History of the Abbots of Wearmouth and Jarrow"). In Abbots of Wearmouth and Jarrow. Edited and translated by Christopher Grocock and Ian N. Wood, 22-75. Oxford: Clarendon Press, 2013.

Bede. Historia ecclesiastica. In Bede's Ecclesiastical History of the English People. Edited and translated by Bertram Colgrave and Roger A.B. Mynors. Oxford: Clarendon Press, 1969.

Bede. The Nature of Things and On Times. Translated by Calvin B. Kendal and Faith Wallis. Liverpool: Liverpool University Press, 2010.

Bede. The Reckoning of Time. Translated by Faith Wallis. Liverpool: Liverpool University Press, 1999.

Bede. De temporibus liber. Edited by Charles W. Jones. CCSL 123C, 579-611. Brepols: Turnhout, 1980.

104 Gregory the Great, Registrum Epistularum, 11.56, ed. Norberg, 961-962: [...] qui summum locum ascendere nititur, gradibus vel passibus non autem saltibus elevator. Bede, Historia ecclesiastica, 1.30, ed. and trans. Colgrave and Mynors, 106-109. See also Dunn, The Christianization of the Anglo-Saxons, 56; Markus, "Gregory the Great and a Papal Missionary Strategy.” 
Bede. De temporum ratione. Edited by Charles W. Jones. CCSL 123B, 241-544. Brepols: Turnhout, 1977.

The Earliest Life of Gregory the Great. Edited and translated by Bertram Colgrave. 2nd ed. Cambridge: Cambridge University Press, 1985.

Eddius Stephanus. Vita Wilfridi. Edited and translated by Bertram Colgrave. The Life of Bishop Wilfrid, Cambridge: Cambridge University Press, 1927.

Gregory the Great. Dialogi. Edited by Adalbert de Vogüé. Translated by Paul Antin. Dialogues, SC 251, 260, 265. Paris: Éditions du Cerf, 1978-1980.

Gregory the Great. Saint Gregory the Great, Dialogues. Translated by Odo John Zimmerman. Vol. 39, The Fathers of the Church. Washington, D.C.: Catholic University of America Press, 1959.

Gregory the Great. Gregorii Magni Dialogi libri IV. Edited by Umberto Moricca. Vol. 57, Fonti per la storia d'Italia. Roma: Tipografia del Senato, 1924.

Gregory the Great. Homilia in Evangelia. Edited and translated by Raymond Étaix, Georges Blanc and Bruno Judic. Homélies sur l'Évangile, 2 vols. Paris: Éditions du Cerf, 2005-2008.

Gregory the Great. Registrum Epistularum. Edited by Dag Norberg. CCSL 140A. Brepols: Turnhout, 1982.

The Letters of Saint Boniface. Edited by Ephraim Emerton. 2nd ed. New York: Norton, 1976.

Mansi, Giovanni Domenico. Sacrorum Conciliorum Nova et Amplissima Collectio. Vol. 3. Florence: Antonius Zatta, 1759.

Paenitentiale Theodori, Discipulus Umbrensium. In Die Canones Theodori Cantuariensis und ihre Überlieferungsformen, edited by Paul Willem Finsterwalder, 285-334. Weimar: Böhlau, 1929.

Rufinus. "On the Creed." Translated by William Henry Fremantle. Vol. 3, Nicene and Post-Nicene Fathers. 2nd ser. 541-562. Peabody: Hendrickson, 1999.

Transitus Beati Fursei: A Translation of the Eighth-Century Manuscript Life of St Fursey. Translated by Oliver Rackham. Norwich: Fursey Pilgrims, 2007.

\section{Secondary Literature}

Alexander, Shirley. "Daniel Themes on the Irish High Crosses." In The Insular Tradition, edited by Catherine E. Karkov, Michael Ryan and Robert T. Farrell, 99-114. Albany: State University of New York Press, 1997.

Anderson, Earl A. Folk-Taxonomies in Early English. Cranbury: Associated University Presses, 2003.

Badcock, Francis J. History of the Creeds. 2nd ed. London: Society for the Promotion of Christian Knowledge, 1938.

Barber, Paul. Vampires, Burial and Death. Folklore and Reality. New Haven: Yale University Press, 1988.

Barrett, Justin L. Why Would Anyone Believe in God? Walnut Creek: AltaMira Press, 2004.

Beckwith, John. Ivory Carvings in Early Medieval England. London: Harvey Miller and Medcalf, 1972.

Bierbrauer, Volker. "The Cross Goes North: From Late Antiquity to Merovingian Times South and North of the Alps." In The Cross Goes North. Processes of Conversion in Northern Europe AD 300-1300, edited by Martin 0. H. Carver, 429-442. Woodbridge: Boydell, 2005.

Blair, John. The Church in Anglo-Saxon Society. Oxford: Oxford University Press, 2005.

Boyer, Pascal. Religion Explained: The Human Instincts That Fashion Gods, Spirits and Ancestors. London: Vintage, 2002.

Bremmer, Jan N. The Early Greek Concept of the Soul. Princeton: Princeton University Press, 1983.

Brenk, Beat. Tradition und Neuerung in der christlichen Kunst des ersten Jahrtausends. Studien zur Geschichte des Weltgerichtsbildes. Vol. 3, Wiener Byzantinistische Studien. Wien: Böhlau, 1966. 
Bynum, Caroline Walker. The Resurrection of the Body in Western Christianity, 200-1336. Vol. 15, Lectures on the Histories of Religions N.S. New York: Columbia University Press, 1995.

Chazelle, Celia. "Art and Reverence in Bede's Churches at Wearmouth and Jarrow." In Intellektualisierung und Mystifizierung mittelalterlicher Kunst. "Kultbild": Revision eines Begriffs, edited by Martin Büchsel and Rebecca Müller, 79-98. Neue Frankfurter Forschungen zur Kunst 10. Berlin: Mann, 2010.

Ciccarese, Maria Pia. “Le Visioni di S. Fursa.” Romanobarbarica 8 (1984-1985): 231-303.

Clayton, Mary. The Cult of the Virgin Mary in Anglo-Saxon England. Cambridge Studies in AngloSaxon England 2. Cambridge: Cambridge University Press, 1990.

Clayton, Mary. The Apocryphal Gospels of Mary in Anglo-Saxon England. Vol. 26, Cambridge Studies in Anglo-Saxon England 26. Cambridge: Cambridge University Press, 1998.

Clemoes, Peter. "Mens absentia cogitans in The Seafarer and The Wanderer." In Medieval Literature and Civilisation: Studies in Memory of G. N. Garmonsway, edited by Derek A. Pearsall and Ronald A. Waldron, 62-77. London: Athlone, 1969.

Cockerton, R. W. P. “The Wirksworth Slab.” Derbyshire Archaeological Journal 82 (1962): 1-20.

Dal Santo, Matthew. Debating the Saints' Cult in the Age of Gregory the Great. Oxford: Oxford University Press, 2012.

Darby, Peter. Bede and the End of Time. Farnham: Ashgate, 2012.

Darby, Peter. "Bede, Iconoclasm and the Temple of Solomon." Early Medieval Europe 21, no. 4 (2013): 390-421.

Declercq, Georges. Anno Domini. The Origins of the Christian Era. Turnhout: Brepols, 2000.

Demacopoulos, George. "Gregory the Great and the Pagan Shrines of Kent." Journal of Late Antiquity 1, no. 2 (2008): 353-369.

Dunn, Marilyn. The Christianization of the Anglo-Saxons c. 597 - c. 700. Discourses of Life, Death and Afterlife. London: Continuum, 2009.

Dunn, Marilyn. "Intuiting Gods. Creed and Cognition in the Fourth Century." Historical Reflections / Reflexions Historiques 38, no. 3 (2012): 1-23.

Dunn, Marilyn. Belief and Religion in Barbarian Europe c. 350 - 700. London: Bloomsbury, 2013.

Elliott, James K. The Apocryphal New Testament. Oxford: Clarendon Press, 1993.

Gaillard de Sémainville, Henri. "Nouvel examen de la plaque-boucle mérovingienne de Landelinus découverte à Ladoix-Serrigny (Côte-d'Or). Apocalypse et millénarisme dans l'art mérovingien." Revue Archéologique de l'Est 52 (2003): 297-327.

Geary, Patrick. "The Uses of Archaeological Sources for Religious and Cultural History." In Living with the Dead in the Middle Ages, edited by Patrick Geary, 30-45. Ithaca: Cornell University Press, 1994.

Gennep, Arnold van. The Rites of Passage. Chicago: Chicago University Press, 1960.

Gifford, Paul. "African Christianity and the Eclipse of the Afterlife." In The Church, the Afterlife and the Fate of the Soul, edited by Peter Clark and Tony Claydon, 413-429. Vol. 45, Studies in Church History. Woodbridge: Boydell, 2009.

Godden, Malcolm R. "Anglo-Saxons on the Mind." In Learning and Literature in Anglo-Saxon England: Studies Presented to Peter Clemoes on the Occasion of his Sixty-Fifth Birthday, edited by Michael Lapidge and Helmut Gneuss, 271-298. Cambridge: Cambridge University Press, 1985.

Gurevich, Aaron I. Categories of Medieval Culture. London: Routledge, 1985.

Hanson, Richard. P. C. The Search for the Christian Doctrine of God. The Arian Controversy 318-381. Edinburgh: T. and T. Clark, 1988.

Harbison, Peter. The High Crosses of Ireland. An Iconographical and Photographic Survey. Vol. 17, Römisch-Germanisches Zentralmuseum, Forschungsinstitut für Vor- und Frühgeschichte, Monographien. 3 vols. Bonn: Rudolf Habelt, 1992. 
Harbison, Peter. "Two Panels on the Wirksworth Slab." Derbyshire Archaeological Journal 107 (1987): 36-40.

Hawkes, Jane. "The Wirksworth Slab. An Iconography of Humilitas." Peritia 9 (1994): 246-289. Hawkes, Jane. "The Rothbury Cross. An Iconographic Bricolage." Gesta 35, no. 1 (1996): 77-94. Hawkes, Jane. "The Road to Hell: The Art of Damnation in Anglo-Saxon Sculpture." In Listen, O Isles Unto Me. Studies in Medieval Word and Image in Honour of Jennifer O'Reilly, edited by Elizabeth Mullins and Diarmuid Scully, 230-242. Cork: Cork University Press, 2011.

Herrmann, John, and Annewies van den Hoek. "Apocalyptic Themes in the Monumental and Minor Art of Early Christianity." In Apocalyptic Thought in Early Christianity, edited by Robert J. Daly, 33-80. Grand Rapids: Baker Academic, 2009.

Hertz, Robert. "A Contribution to the Study of the Collective Representation of Death." In Death and the Right Hand, edited by Rodney Needham and Claudia Needham, 27-86. Aberdeen: Cohen and West, 1960.

Hines, John, and Alex Bayliss, eds. Anglo-Saxon Graves and Grave-Goods of the 6th and 7th Centuries AD: A Chronological Framework. London: Society for Medieval Archaeology, 2013.

Ireland, Colin. "Some Irish Characteristics of the Whitby Life of Gregory the Great." In Early Medieval Ireland and Europe: Chronology, Contacts, Scholarship. A Festschrift for Dáibhí Ó Cróinín, edited by Pádraic Moran and Immo Warntjes, 139-178. Vol. 14, Studia traditionis theologiae. Turnhout: Brepols, 2015.

Jeffery, C. D. “The Latin Texts Underlying The Old English Gregory's Dialogues and Pastoral Care." Notes and Queries, N. S., 27 (1980): 483-488.

Kabir, Ananya Jahanara. Paradise, Death and Doomsday in Anglo-Saxon Literature. Vol. 32, Cambridge Studies in Anglo-Saxon England. Cambridge: Cambridge University Press, 2001.

Karkov, Catherine E. "The Bewcastle Cross. Some Iconographic Problems.” In The Insular Tradition, edited by Catherine E. Karkov, Michael Ryan and Robert T. Farrell. 9-26. Albany: State University of New York Press, 1997.

Lockett, Leslie. "The Limited Role of the Brain in Mental and Emotional Activity According to AngloSaxon Medical Learning." In Anglo-Saxon Emotions. Reading the Heart in Old English Language, Literature and Culture, edited by Alice Jorgensen, Frances McCormack and Jonathan Wilcox, 35-51. Farnham: Ashgate 2015.

Lockett, Leslie. Anglo-Saxon Psychologies in the Vernacular and Latin Traditions. Toronto AngloSaxon Series 8. Toronto: University of Toronto Press, 2011.

MacCulloch, John A. The Harrowing of Hell. A Comparative Study of an Early Christian Doctrine. Edinburgh: T. \& T. Clark, 1930.

Machielsen, Lambertus. "Fragments patristiques non-identifiés du Ms. Vat. Pal. 577." Sacris Erudiri 12 (1961): 488-539.

Markus, Robert. "Gregory the Great and a Papal Missionary Strategy." In The Mission of the Church and the Propagation of the Faith, edited by Geoffrey J. Cuming, 29-38. Vol. 6, Studies in Church History. Cambridge: Cambridge University Press, 1970.

Meens, Rob. "With One Foot in the Font: The Failed Baptism of the Frisian King Radbod and the 8thCentury Discussion about the Fate of Unbaptized Forefathers." In Early Medieval Ireland and Europe: Chronology, Contacts, Scholarship. A Festschrift for Dáibhí Ó Cróinín, edited by Pádraic Moran and Immo Warntjes, 577-596. Vol. 14, Studia traditionis theologiae. Turnhout: Brepols, 2015.

Metcalf, Peter, and Richard Huntington. Celebrations of Death. The Anthropology of Mortuary Ritual. 2nd ed. Cambridge: Cambridge University Press, 1991.

Meyvaert, Paul. "Bede and the Church Paintings at Wearmouth-Jarrow." Anglo-Saxon England 8 (1979): 63-77. 
Michelli, Perette E. "Beckwith Revisited: Some Ivory Carvings from Canterbury." In Anglo-Saxon Styles, edited by Catherine E. Karkov and George Hardin Brown, 101-114. Albany: State University of New York Press, 2003.

Ó Carragáin, Éamonn. "The Ruthwell Crucifixion Poem in its Iconographic and Liturgical Contexts." Peritia 6-7 (1987-1988): 1-71.

Ó Carragáin, Éamonn. Ritual and the Rood: Liturgical Images and the Old English Poems of the Dream of the Rood Tradition. London: British Library, 2005.

Ó Carragáin, Éamonn. "Christian Inculturation in Eighth-Century Northumbria: The Bewcastle and Ruthwell Crosses." Colloquium Journal 4 (2007) [accessed 1 April 4, 2019], http://ism.yale. edu/sites/default/files/files/Christian\%20Inculturation\%20in\%20Eighth.pdf.

Ó hÓgáin, Dáithi. The Sacred Isle. Belief and Religion in Pre-Christian Ireland. Woodbridge: Boydell, 1999.

Owen, Douglas D. R. The Vision of Hell. Infernal Journeys in Medieval French Literature. Edinburgh: Scottish Academic Press, 1970.

Page, Raymond I. "The Bewcastle Cross." In Runes and Runic Inscriptions. Collected Essays on Anglo-Saxon and Viking Runes, edited by Raymond Page, 47-70. Woodbridge: Boydell, 1996.

Palmer, James T. The Apocalypse in the Early Middle Ages. Cambridge: Cambridge University Press, 2014.

Palmer, James T. "The Ends and Futures of Bede's De temporum ratione." In Bede and the Future, edited by Peter Darby and Faith Wallis, 139-160. Farnham: Ashgate, 2014.

Pentikäinen, Juha. “The Dead Without Status.” Temenos 4 (1969): 92-102.

Phillips, Michael Joseph. "Heart, Mind and Soul in Old English: A Semantic Study." PhD diss., University of Illinois at Urbana-Champaign, 1985.

Pluskowski, Aleks. "Apocalyptic Monsters: Animal Inspirations for the Iconography of Medieval North European Devourers." In The Monstrous Middle Ages, edited by Bettina Bildhauer and Robert Mills, 155-176. Cardiff: University of Wales Press, 2003.

Rambaran-Olm, Mary R. John the Baptist's Prayer or the Descent into Hell from the Exeter Book. Vol. 21, Anglo-Saxon Studies. Cambridge: D. S. Brewer, 2014.

Schapiro, Meyer. “Cain's Jaw-Bone that Did the First Murder." The Art Bulletin 24, no. 3 (1942): 205-212.

Schmidt, Gary D. The Iconography of the Mouth of Hell: Eighth-Century Britain to the Fifteenth Century. London: Associated University Presses, 1995.

Semple, Sarah. "A Fear of the Past: The Place of the Prehistoric Burial Mound in the Ideology of Middle and Later Anglo-Saxon England." World Archaeology 30, no. 1 (1998): 109-126.

Shippey, Thomas A. Beowulf. Vol. 70, Studies in English Literature. London: Edward Arnold, 1978.

Stanton, Robert. "Mimicry, Subjectivity and the Embodied Voice in Anglo-Saxon Bird-Riddles." In Voice and Voicelessness in Medieval Europe, ed. Irit Ruth Kleiman, 29-43. Basingstoke: Palgrave Macmillan, 2005.

Thompson, Victoria. Dying and Death in Later Anglo-Saxon England. Anglo-Saxon Studies 4. Woodbridge: Boydell, 2004.

Tolley, Clive. "Oswald's Tree." In Pagans and Christians. The Interplay between Christian Latin and Traditional Germanic Cultures in Early Medieval Europe, edited by Tette Hofstra, Luuk A. J. R. Houwen and Alasdair A. MacDonald, 149-173. Vol. 2, Germania Latina. Groningen: Egbert Forsten, 1995.

Treffort, Cécile. "Vertus prophylactiques et sens eschatologique d'un dépôt funéraire du haut Moyen Âge. Les plaques boucles rectangulaires burgondes à inscription.” Archéologie Médievale 32 (2002): 31-53. 
Walther, Otto Kenneth. "Codex Laudianus G 35, A Re-Examination of the Manuscript. Including a Reproduction of the Text and an Accompanying Commentary." PhD diss., University of St Andrews, 1980.

Whitehouse, Harvey, and Luther H. Martin, eds. Theorizing Religions Past. Archaeology, History and Cognition. Walnut Creek: AltaMira Press, 2004.

Williams, Howard. "Monuments and the Past in Early Anglo-Saxon England." World Archaeology 31, no. 1 (1998): 90-109.

Wilson, David. Anglo-Saxon Paganism. London: Routledge, 1992.

Yerkes, David. “An Unnoticed Omission in the Modern Critical Editions of Gregory's 'Dialogues'.” Revue Bénédictine 87, no. 1-2 (1977): 178-179.

Young, Bailey K. "The Imagery of Personal Objects: Hints of 'Do-It-Yourself' Christian Culture in Merovingian Gaul?" In The Power of Religion in Late Antiquity, edited by Andrew Cain and Noel Lenski, 229-254. Farnham: Ashgate, 2009. 